DOI: https://doi.org/10.47405/mjssh.v6i6.818

\begin{tabular}{|c|c|}
\hline$y_{x=1}$ & Malaysian Journal of Social Sciences and Humanities (MJSSH) \\
\hline $\begin{array}{l}\text { Malaysian Journal of } \\
\text { Socrai scciecces and }\end{array}$ & Volume 6, Issue 6, June 2021 \\
\hline (MJ-SSH) & e-ISSN : 2504-8562 \\
\hline & $\begin{array}{l}\text { Journal home page: } \\
\text { www.msocialsciences.com }\end{array}$ \\
\hline
\end{tabular}

\title{
Amalan Efikasi Guru dan Hubungan dengan Kepedulian Kerja Guru MRSM
}

\author{
Faridah Darus ${ }^{1}$, Mohd Khairuddin @Jerry Abdullah ${ }^{1}$ \\ 1Fakulti Psikologi dan Pendidikan, Universiti Malaysia Sabah (UMS), Malaysia \\ Correspondence: Faridah Binti Darus (artikelfd@gmail.com)
}

\begin{abstract}
Abstrak
Penyelidikan ini dijalankan bertujuan mengenal pasti tahap dan hubungan efikasi guru dengan kepedulian kerja guru serta melihat pengaruh efikasi guru terhadap kepedulian kerja guru Maktab Rendah Sains MARA. Kajian menggunakan kaedah tinjauan. Beberapa teknik pensampelan digunakan iaitu pensampelan tiga tahap iaitu tahap satu (1) ialah pensampelan rawak kelompok besar; tahap dua (2) ialah pensampelan rawak kelompok kecil dalam kelompok besar; tahap tiga (3) ialah pensampelan rawak elemen dalam kelompok kecil dengan mengedarkan satu set borang soal selidik yang telah diadaptasi daripada penyelidik asal. Seramai 363 orang responden yang terdiri daripada ketua-ketua jabatan akademik dan guru-guru kanan subjek di 20 buah MRSM seluruh Malaysia telah menjawab soal selidik yang diedarkan. Data dianalisis menggunakan perisian IBM SPSS. Dapatan kajian menunjukkan tahap efikasi guru MRSM adalah tinggi dan memiliki hubungan yang kuat dengan kepedulian kerja guru. Seterusnya pengaruh efikasi guru terhadap kepedulian kerja guru pada nilai $\mathrm{r}^{2}=$ 0.267 pada nilai signifikan $\mathrm{p}<0.05$ menunjukkan hanya strategi pengajaran dan penglibatan murid berupaya menjadi pengaruh kepada kepedulian kerja guru.
\end{abstract}

Kata kunci: efikasi guru, kepedulian kerja guru, MRSM

\section{Teacher Effectiveness Practice and Relationship with MRSM Teacher Work Concern}

\begin{abstract}
This research was conducted to identify the level and relationship of teacher effectiveness with teacher work care and to see the influence of teacher effectiveness on teacher work care MARA Science Junior College. The study used a survey method. Several sampling techniques are used, namely three -level sampling, namely level one (1) is large group random sampling; stage two (2) is random sampling of small clusters within large clusters; level three (3) is random sampling of elements in small groups by distributing a set of questionnaires that have been adapted from the original researcher. A total of 363 respondents consisting of heads of academic departments and senior subject teachers in 20 MRSM`s throughout Malaysia answered the questionnaire distributed. Data were analyzed using IBM SPSS software. The findings of the study show that the level of effectiveness of MRSM teachers is high and has a strong relationship with the work of teachers. Furthermore, the influence of teacher effectiveness on teacher work care at a value of $\mathrm{r}^{2} 26.7 \%$ shows that only teaching strategies and student involvement can be an influence on teacher work care.
\end{abstract}

Keywords: teacher effectiveness, teacher work concern, MRSM 


\section{Pengenalan}

Jika diteliti dengan mendalam, efikasi ini berlainan dengan aspirasi (cita-cita), kerana cita-cita berkaitan sesuatu yang ideal yang seharusnya dapat dicapai, namun begitu efikasi menggambarkan pencapaian kebolehan diri. Tschannen, Hoy dan Hoy (1998) telah menghasilkan satu model tentang efikasi guru iaitu menerangkan keyakinan dan kemampuan diri guru untuk melaksanakan sesuatu kerja. Hal ini, sama seperti teori sains kognitif Bandura (1986; 1997), terdapat empat perkara yang mempengaruhi keyakinan efikasi iaitu isyarat psikologi, pujukan lisan, perwakilan pengalaman dan pengalaman masteri. Kajian Khalid (2016) menunjukkan kaitan efikasi guru dengan pengurusan kelas membuktikan guru-guru menerima pengaruh yang lebih besar. Kajian Mohd Mahadzir (2014) pula pihak MARA menyediakan perancangan yang bersesuaian untuk meningkatkan efikasi guru pada tahap yang tinggi dan positif. Kajian Lee (2016) pula mengatakan para pemimpin pendidikan digalakkan untuk melaksanakan pengupayaan, memperkemas hubungan interpersonal, mendelegasikan kerja serta berkolaboratif dengan sub-ordinatnya bagi mendapat pencapaian akademik yang lebih positif.

Efikasi guru sering dikaitkan dengan kepedulian kerja guru. Bagi Hall \& Hord (2011) kepedulian merangkumi perasaan, fikiran serta tindak balas terhadap sesuatu perubahan atau amalan baharu yang mempengaruhi kehidupan seseorang. Kepedulian melibatkan perkembangan dalam proses perubahan. Seseorang guru yang berpengalaman akan menjadi seperti guru novis apabila sesuatu kurikulum baharu diimplementasikan (Hall \& Hord, 2011). Oleh yang demikian, kepedulian seseorang menunjukkan tahap yang paling tinggi pada peringkat awal amalan baharu iaitu peringkat kepedulian diri. Oleh itu, apabila seseorang menjadi lebih berpengalaman dalam melaksanakan amalan baharu, tahap itu akan beralih kepada peringkat kepedulian tugas dan seterusnya kepada peringkat kepedulian impak (Hall \& Hord, 2011). Model Penerimaan Berasaskan Kepedulian atau Concerns Based Adoption Model (CBAM) daripada hasil kerja Fuller (1969) adalah berkaitan dengan pendekatan amalan baharu terhadap perubahan pendidikan. Model CBAM telah diamalkan untuk merancang pembangunan guru yang melibatkan amalan baharu pendidikan. Kajian oleh Zaidir (2017) menyatakan guru-guru seharusnya diberi pendedahan dengan konsep amalan baharu dalam pendidikan. Hal ini kerana amalan baharu pendidikan telah membawa perubahan yang amat besar kepada guru dalam mengendalikan pengajaran dan pembelajaran dalam bilik darjah. Amalan baharu tersebut membolehkan guru-guru menggunakan strategi serta teknik yang berbagai-bagai bagi melibatkan murid dengan aktif. Setiap sekolah perlu memberi sokongan yang padu bagi menggalakkan amalan baharu pendidikan dalam kalangan guru ini berlaku. Oleh yang demikian, kajian ini mengkaji mengenai tahap amalan efikasi guru dan hubungan dengan kepedulian kerja guru di Maktab Rendah Sains MARA (MRSM).

\section{Sorotan Literatur}

Efikasi guru, juga dikenali sebagai efikasi kendiri pengajaran iaitu kepercayaan guru berkaitan dengan kecekapannya untuk menolong murid belajar (Pintrich \& Schunk, 2002). Ghaith dan Yaghi (1997) dalam kajian menunjukkan bahawa guru dengan efikasi pengajaran yang tinggi akan lebih meminati untuk mengaplikasikan kaedah pengajaran yang baru dan mereka tidak bersungut tentang kesukaran bagi melaksanakan aktiviti pengajaran dengan kaedah baru tersebut berbanding dengan guru yang memiliki efikasi yang rendah. Guru-guru yang mempunyai efikasi pengajaran yang tinggi boleh menggunakan kaedah pengajaran baru seperti penggunaan pembelajaran koperatif dalam pembelajaran untuk diajar di dalam bilik darjah. Kajian oleh Poulou (2007) menunjukkan bahawa efikasi guru adalah perkara utama kejayaan sebagai seorang guru yang menimbulkan kesan kepada kejayaan dalam bilik darjah (Poulou, 2007).

Teori yang dibincangkan dalam kajian ini ialah teori kognitif sosial yang dikemukakan oleh Bandura (1986, 1997). Hubungan antara keberkesanan guru dengan pencapaian pelajar adalah berkait rapat tetapi peningkatan efikasi memberi sumbangan penting terhadap pembelajaran pelajar dan pada kepimpinan guru (Muijs \& Reynolds, 2001). Kajian yang dilakukan Giallo dan Little (2003) mendapati wujud hubungan yang positif efikasi dalam persediaan dan pengalaman di bilik darjah. Juga didapati aspek kesediaan dan pengalaman bilik darjah adalah peramal yang signifikan efikasi guru dalam pengurusan tingkah laku. Berdasarkan sorotan-sorotan kajian di atas, efikasi guru yang dimaksudkan 
dalam kajian ini adalah efikasi guru yang meliputi aspek efikasi dalam strategi pengajaran, penglibatan murid dan pengurusan bilik darjah.

Kajian Lezah (2018), guru berperanan penting memilih kaedah pengajaran yang bersesuaian kerana aspek kepedulian guru untuk menerima perubahan dengan memenuhi kehendak murid sepanjang proses pengajaran dan pembelajaran bagi memastikan objektif pengajaran dan pembelajaran dapat dicapai. Kajian oleh Zaidir (2017) menyatakan guru-guru seharusnya diberi pendedahan dengan konsep amalan baharu dalam pendidikan. Norazlin dan Siti Rahaimah (2018) membuktikan bahawa guru mempunyai pandangan positif tentang pembelajaran abad ke-21 tetapi mereka masih perlu membuat penambahbaikan dalam amalan pengajaran. Selain itu, kajian oleh Norazlin Mohd Rusdin (2018) membuktikan persepsi dan pemahaman guru terhadap amalan baharu dalam pendidikan mempengaruhi tindakan, keputusan dan amalan mereka di dalam kelas. Kajian oleh Susan et.al. (2018) adalah untuk mengkaji kepedulian guru terhadap penggunaan kemahiran berfikir komputasi dalam pengajaran dan pembelajaran mereka. Kajian ini menggunakan Model Adopsi Berdasarkan Keprihatinan (CBAM) bagi mengenal pasti tahap kepedulian $(\mathrm{SoC})$ responden. Penemuan ini juga menunjukkan bahawa responden menunjukkan kebimbangan yang minima tetapi berminat dan memerlukan lebih banyak maklumat tentang cara untuk menerapkan kemahiran berfikir komputasi dalam pengajaran dan pembelajaran.

\section{Metod Kajian}

Kajian ini menggunakan model dan pendekatan berdasarkan Model Penerimaan Berasaskan Kepedulian atau Concerns Based Adoption Model (CBAM) daripada hasil kerja Fuller (1969) yang berkaitan dengan pendekatan amalan baharu terhadap perubahan pendidikan. Hall dan Hord (1987) mengkategorikan pembuat dasar, pemimpin sekolah seperti pengetua dan ketua jabatan dan guru sebagai fasilitator perubahan. Mereka yang bertanggungjawab sebagai fasilitator perubahan dan faktor yang akan memastikan kejayaan dan kegagalan sesuatu amalan baharu pendidikan. Hal ini menunjukkan peranan yang dilakukan oleh kepimpinan sekolah dalam memastikan kejayaan sesuatu pembangunan pendidikan di sekolah. Rajah 1 menunjukkan kerangka konseptual kajian ini.

\section{Rajah 1: Kerangka Konseptual}

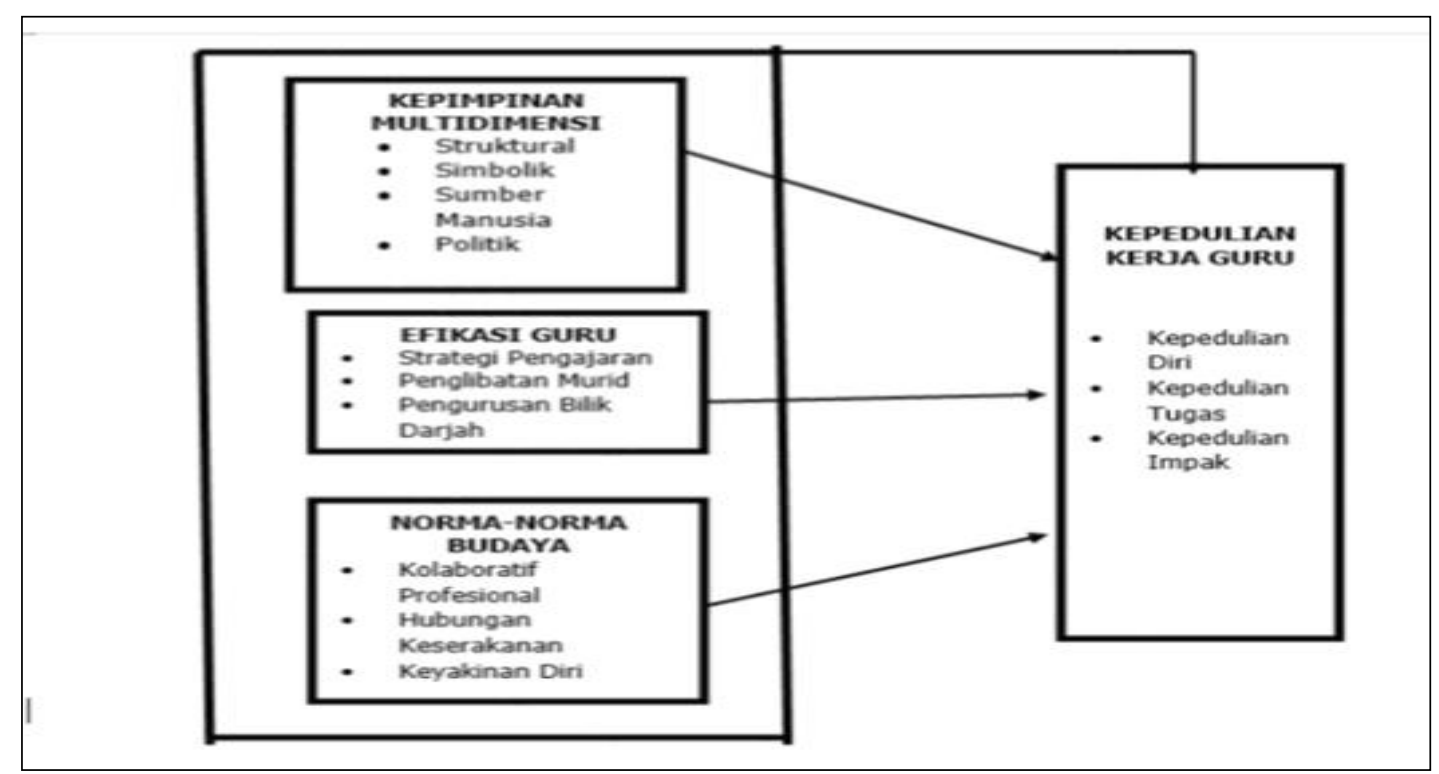

Sumber: Hall dan Hord (2006)

Reka bentuk kajian ini adalah kajian kuantitatif. Proses pengumpulan data kajian telah menggunakan kaedah tinjauan bagi mengetahui penilaian dan fenomena pengaruh pemboleh ubah bebas ke atas pemboleh ubah bersandar, satu tinjauan yang meluas diperlukan ke atas populasi yang besar dan dalam kajian ini iaitu ketua-ketua jabatan akademik dan guru-guru kanan subjek MRSM di seluruh Malaysia. 
pengkaji menetapkan saiz sampel seramai 363 orang selari dengan rules of thumb yang dicadangkan oleh Roscoe (1975) yang menyatakan bahawa saiz sampel yang lebih besar daripada 30 dan lebih kecil daripada 500 adalah sesuai untuk kebanyakan kajian (Sekaran, 2000). Pemilihan sampel dengan teknik ini melibatkan pemilihan kelompok dalam kelompok (Gay \& Diehl, 1996). Kajian ini menggunakan persampelan tiga tahap (three stag sampling) iaitu tahap satu (1) ialah pensampelan rawak kelompok besar; tahap dua (2) ialah persampelan rawak kelompok kecil dalam kelompok besar; tahap tiga (3) ialah persampelan rawak elemen dalam kelompok kecil (Neuman, 2006).

Instrumen kajian untuk efikasi ialah TSES (Teacher Sense of Efficacy Scale) pada asalnya dalam versi bahasa Inggeris tetapi telah dibuat proses back to back translation oleh Khalid (2009) dan seterusnya instrumen ini juga digunakan oleh Khalid Johari (2009), Faridah Abdullah (2014), Dewi (2015), Haidi (2019) dalam kajian PhD mereka. Bagi mengukur kepedulian kerja guru, pengkaji menggunakan item yang dibuat penyesuaian daripada soal selidik Hall et al. (1977). Instrumen ini telah melalui semakan yang mendalam oleh panel pakar dalam bidang kajian ini. Panel pakar telah menentukan instrumen yang digunakan ini benar-benar mengukur penguasaan kemahiran tertentu. Instrumen ini juga dinilai untuk memastikan kandungan soal selidik ini hanya mengandungi perkara yang hendak diukur sahaja.

Kajian rintis dilaksanakan untuk menguji instrumen yang digunakan sama ada ia memenuhi ciri-ciri kebolehpercayaan. Kajian ini telah melakukan ujian rintis bagi memastikan instrumen kajian jelas, menarik, tidak mengelirukan responden, tekal dan mudah difahami.

Kajian rintis yang telah dilaksanakan oleh pengkaji melalui pentadbiran yang sama dengan kajian sebenar. Setelah kajian rintis dijalankan, nilai pekali Cronbach Alpha dinilai untuk memastikan tahap kebolehpercayaan instrumen bagi kajian ini. Pengkaji telah mengambil 111 orang responden ketuaketua jabatan dan guru-guru kanan subjek di lima buah MRSM seluruh Malaysia. Responden yang dipilih bagi menjalani kajian rintis ini memiliki ciri-ciri yang hampir sama dengan responden bagi kajian sebenar. Instrumen soal selidik yang digunakan dalam kajian ini memiliki kebolehpercayaan yang tinggi dan boleh digunakan tanpa melalui proses penambahbaikan, pengubahsuaian, dan juga penyingkiran.

Analisis statistik deskriptif digunakan untuk menghuraikan data mentah supaya boleh difahami dengan melakukan penyusunan secara bermakna. Analisis statistik deskriptif digunakan untuk menghuraikan melalui ukuran kecenderungan memusat (min), indeks kebolehubahan (sisihan piawai) dan juga peratusan dan kekerapan. Tambahan pula, ujian kecenderungan memusat, indeks kebolehubahan, peratusan dan kekerapan digunakan untuk memberi gambaran mengenai tahap efikasi guru .

Jadual 1: Interpretasi Skor Min Efikasi Guru

\begin{tabular}{cc}
\hline Skor Min & Aras \\
\hline $6.34-9.00$ & Tinggi \\
$3.67-6.33$ & Sederhana \\
$1.00-3.66$ & Rendah \\
\hline
\end{tabular}

Sumber: Haidi (2018) dan Faridah (2014)

Jadual 2 : Interpretasi Skor Min Kepedulian Kerja Guru

\begin{tabular}{cc}
\hline Skor Min & Aras \\
\hline $3.68-5.00$ & Tinggi \\
$1.35-3.67$ & Sederhana \\
$1.00-1.34$ & Rendah \\
\hline
\end{tabular}

Sumber: Creswell (2009)

Ujian Korelasi Pearson telah digunakan dalam kajian ini untuk mencari hubungan amalan efikasi guru kepedulian kerja guru. 
DOI: https://doi.org/10.47405/mjssh.v6i6.818

Jadual 3: Takrifan Kekuatan Korelasi

\begin{tabular}{cc}
\hline Indeks & Penerangan \\
\hline $0.00-0.19$ & Sangat Rendah \\
$0.20-0.39$ & Rendah \\
$0.40-0.59$ & Sederhana \\
$0.60-0.79$ & Tinggi \\
$0.80-1.00$ & Sangat Tinggi \\
\hline
\end{tabular}

Sumber: Evans (1996)

Jadual 4: Pengaruh Efikasi Guru Terhadap Kepedulian Kerja Guru

\begin{tabular}{lllllll}
\hline & \multicolumn{2}{c}{$\begin{array}{c}\text { Unstandardized } \\
\text { Coefficients }\end{array}$} & \multicolumn{2}{c}{$\begin{array}{c}\text { Standardized } \\
\text { Coefficients }\end{array}$} \\
\hline \multirow{3}{*}{1} & Model & B & Std. Error & Beta & Ujian t & Nilai p. \\
(Pemalar) & 2.186 & .165 & & 13.241 & .000 \\
& Strategi Pengajaran & .133 & .035 & .320 & 3.797 & .000 \\
Penglibatan Murid & .091 & .036 & .223 & 2.485 & .013 \\
Pengurusan Bilik & .000 & .037 & -.001 & -.007 & .994 \\
Darjah & & & & & \\
\hline
\end{tabular}

\section{Dapatan Kajian}

Jadual 5 menunjukkan tahap amalan efikasi guru. Tahap amalan efikasi guru berada pada tahap yang tinggi (Min=7.73, SP=0.728). Berdasarkan skor min dalam tiga amalan efikasi guru jelas menunjukkan taburan skor min tertinggi adalah pengurusan bilik darjah $(\mathrm{Min}=7.84, \mathrm{SP}=0.753)$, strategi pengajaran (Min=7.69, SP=0.788), dan penglibatan murid (Min=7.67, SP=0.809). Kesimpulannya, tahap amalan efikasi guru berada pada tahap yang tinggi dan berada pada skor julat skor min tinggi (6.34- 9.00).

Jadual 5: Dimensi Efikasi Guru

\begin{tabular}{llll}
\hline Dimensi Efikasi & Min & SP & Tahap \\
\hline Strategi Pengajaran & 7.69 & .788 & Tinggi \\
Penglibatan Murid & 7.67 & .809 & Tinggi \\
Pengurusan Bilik Darjah & 7.84 & .753 & Tinggi \\
\hline Efikasi & 7.73 & .728 & \\
\hline
\end{tabular}

Jadual 6 menunjukkan tahap kepedulian kerja guru terhadap kepedulian diri, kepedulian tugas dan kepedulian impak. Dapatan kajian menunjukkan skor min pada tahap yang tinggi iaitu (Min=3.90, $\mathrm{SP}=0.328)$. Kepedulian tugas menunjukkan skor min tertinggi (Min=4.16, $\mathrm{SP}=0.394)$, kepedulian diri (Min=3.94, $\mathrm{SP}=0.345)$, dan kepedulian impak $(\mathrm{Min}=3.76, \mathrm{SP}=0.395)$.

Jadual 6: Dimensi Kepedulian Kerja Guru

\begin{tabular}{lllll}
\hline Dimensi Kepedulian Kerja & Min & SP & Tahap & \\
\hline Kepedulian Diri & 3.94 & .345 & & Tinggi \\
Kepedulian Tugas & 4.16 & .394 & Tinggi & \\
Kepedulian Impak & 3.76 & .395 & Tinggi & \\
\hline Kepedulian Kerja Guru & 3.90 & .328 & & \\
\hline
\end{tabular}

Jadual 7 memaparkan hubungan korelasi positif yang sederhana dan signifikan antara efikasi guru dan kepedulian kerja guru $(\mathrm{r}=.505, \mathrm{p}<.05)$. Pada tahap sederhana antara dimensi efikasi guru dengan 
dimensi kepedulian diri $(\mathrm{r}=.441, \mathrm{p}<.05)$, kepedulian tugas $(\mathrm{r}=.496, \mathrm{p}<.05)$, dan kepedulian impak $(\mathrm{r}=.409, \mathrm{p}<.05)$. Bagi strategi pengajaran, keputusan menunjukkan terdapat hubungan signifikan yang sederhana dengan konstruk kepedulian kerja guru $(\mathrm{r}=.499, \mathrm{p}<.05)$, kepedulian diri $(\mathrm{r}=.417, \mathrm{p}<.05)$, kepedulian tugas $(\mathrm{r}=.480, \mathrm{p}<.05)$ dan kepedulian impak $(\mathrm{r}=.422 \mathrm{p}<.05$,). Penglibatan murid juga menunjukkan hubungan signifikan yang sederhana dengan konstruk kepedulian kerja guru $(\mathrm{r}=.481$, $\mathrm{p}<.05)$, dan kepedulian diri $(\mathrm{r}=.425, \mathrm{p}<.05)$, kepedulian tugas $(\mathrm{r}=.443, \mathrm{p}<.05)$, dan kepedulian impak $(\mathrm{r}=.400, \mathrm{p}<.05)$. Hubungan antara pengurusan bilik darjah dengan konstruk kepedulian kerja guru adalah signifikan serta mempunyai tahap hubungan yang sederhana dan rendah. Keputusan memperlihatkan hubungan yang sederhana adalah dengan kepedulian kerja guru $(r=.426, p<.05)$ dan kepedulian tugas $(\mathrm{r}=.462, \mathrm{p}<.05)$. Namun begitu, kepedulian impak $(\mathrm{r}=.317, \mathrm{p}<.05)$ dan kepedulian diri $(\mathrm{r}=.386, \mathrm{p}<.05)$ menunjukkan hubungan yang rendah. Justeru, keputusan kajian secara keseluruhannya menunjukkan bahawa terdapat hubungan yang signifikan positif yang sederhana dan rendah antara efikasi guru dengan kepedulian kerja guru di MRSM.

Jadual 7: Hubungan Antara Amalan Efikasi Guru Dengan Kepedulian Kerja Guru

\begin{tabular}{|c|c|c|c|c|c|}
\hline & & $\begin{array}{l}\text { Kepedulian } \\
\text { Kerja Guru }\end{array}$ & $\begin{array}{l}\text { Kepedulian } \\
\text { Diri }\end{array}$ & $\begin{array}{l}\text { Kepedulian } \\
\text { Tugas }\end{array}$ & $\begin{array}{l}\text { Kepedulian } \\
\text { Impak }\end{array}$ \\
\hline Efikasi Guru & $\begin{array}{l}\text { Pearson Correlation } \\
\text { Sig. ( } 2 \text { tailed) }\end{array}$ & $.505 * * .000$ & $.441 * * .000$ & $\begin{array}{l}.496 * * \\
.000\end{array}$ & $.409 * * .000$ \\
\hline $\begin{array}{l}\text { Strategi } \\
\text { Pengajaran }\end{array}$ & $\begin{array}{l}\text { Pearson Correlation } \\
\text { Sig. ( } 2 \text { tailed })\end{array}$ & $.499 * * .000$ & $.417 * * .000$ & $\begin{array}{l}.480 * * \\
.000\end{array}$ & $.422 * * .000$ \\
\hline $\begin{array}{l}\text { Penglibatan } \\
\text { Murid }\end{array}$ & $\begin{array}{l}\text { Pearson Correlation } \\
\text { Sig. ( } 2 \text { tailed })\end{array}$ & $.481 * * .000$ & $.425 * * .000$ & $\begin{array}{l}.443 * * \\
.000\end{array}$ & $.400 * * .000$ \\
\hline $\begin{array}{l}\text { Pengurusan } \\
\text { Bilik Darjah }\end{array}$ & $\begin{array}{l}\text { Pearson Correlation } \\
\text { Sig. ( } 2 \text { tailed })\end{array}$ & $.426 * * .000$ & $.386 * * .000$ & $\begin{array}{l}.462 * * \\
.000\end{array}$ & $.317 * * .000$ \\
\hline
\end{tabular}

Dapatan kajian dijalankan bagi mengkaji pengaruh amalan efikasi guru (IV) terhadap kepedulian kerja guru (DV). Ujian Regresi Linear Berganda menunjukkan secara keseluruhan model regresi adalah signifikan $F(3,342)=41.084, p<.05$, dengan nilai $r^{2}=0.267$. Hanya dimensi strategi pengajaran (Beta=.133), $(\mathrm{t}=3.797, \mathrm{p}<.05)$ dan dimensi penglibatan murid (Beta=.091), $(\mathrm{t}=2.485, \mathrm{p}<.05)$ merupakan peramal yang signifikan ke atas kepedulian kerja guru. Manakala dimensi pengurusan bilik darjah (Beta=-.000), (t=-.007, p>.05) bukan peramal kerana melebihi nilai signifikan. Kedua-dua dimensi memberikan nilai peramal yang positif terhadap kepedulian kerja guru. Perihal dapatan ini menunjukkan bahawa aras strategi pengajaran dalam kalangan guru dapat membantu guru melaksanakan kepedulian kerja. Begitu juga dengan penglibatan murid dapat melaksanakan kepedulian kerja guru secara berkesan di MRSM. Rumus regresi berganda bagi model ini adalah $\mathrm{Y}=2.186+$ $0.133 \mathrm{X}_{1}+0.091 \mathrm{X}_{2}$

\section{Perbincangan}

Secara ringkasnya, dapatan kajian menunjukkan tahap amalan efikasi guru di MRSM berada pada tahap tinggi. Tahap kepedulian kerja guru juga berada pada tahap tinggi. Secara keseluruhannya responden merasakan mereka memiliki tahap keyakinan yang tinggi bagi menjayakan tugasan pengajaran yang merangkumi keupayaan melibatkan murid dalam pembelajaran, mewujudkan sistem pengurusan kelas yang boleh dipatuhi oleh semua murid serta mampu dalam mengamalkan strategi pengajaran baharu serta mempelbagaikan kaedah pentaksiran dalam kelas. Kepedulian guru terhadap kerja dinilai dari aspek tahap penerimaan guru-guru terhadap segala amalan baharu dan pembaharuan yang diperkenalkan di MRSM. Dalam hal ini, amat jelas bahawa kepimpinan guru di MRSM perlu mendapat sokongan, dorongan dan bimbingan bagi membolehkan mereka memiliki efikasi yang tinggi agar usaha bersamasama dapat dilakukan dalam pelaksanaan pembangunan amalan baharu pendidikan di MRSM. 
Hasil kajian mendapati wujudnya korelasi positif yang sederhana dan signifikan antara efikasi guru dan kepedulian kerja guru. Hal ini membuktikan efikasi guru membantu dalam melakukan sebarang perubahan dan amalan baharu pendidikan. Namun begitu, terdapat juga hubungan yang rendah dan signifikan bagi dimensi efikasi guru dengan kepedulian kerja guru iaitu pengurusan bilik darjah dengan kepedulian diri dan pengurusan bilik darjah dengan kepedulian impak. Dimensi efikasi guru seperti strategi pengajaran, penglibatan pelajar dan pengurusan bilik darjah mempunyai perkaitan dalam menambahkan penerimaan guru-guru terhadap keperluan kerja di MRSM.

\section{Kesimpulan}

Isu-isu pembangunan pendidikan serta kepedulian kerja guru terhadap tugas akibat daripada pelaksanaan berbagai-bagai program dan amalan-amalan baru yang diperkenal di MRSM dijadikan sebagai sandaran permasalahan kajian ini. Kajian ini mengenal pasti tahap kepedulian kerja guru didapati tinggi dengan keutamaan pada kepedulian. Hal ini dianggap bahawa guru-guru memiliki kepedulian terhadap tugas, memperlihatkan kesediaan guru-guru berkaitan tentang aspek pengurusan iaitu kesan sesuatu perubahan terhadap tugasan, konflik kepentingan diri dan tanggungjawab, kelebihan diri serta masa bagi menyesuaikan diri dengan tugas baharu. Pada peringkat ini, guru-guru telah pun berdepan dengan berbagai-bagai bentuk perubahan dan amalan baharu iaitu guru-guru sudah mengalami banyak pengalaman untuk menghadapinya. Namun begitu, kepedulian guru pada tugasnya memerlukan sokongan semua pihak terutamanya daripada kepimpinan sekolah. Kepedulian kerja peringkat ini menunjukkan guru-guru memiliki kemahuan untuk berkolaborasi dengan rakan sekerja, bersedia untuk memikirkan tentang impak sesuatu perubahan serta memiliki kecenderungan untuk mencari idea-idea lain. Selain itu, peringkat ini memperlihatkan bahawa guru-guru telah bersedia untuk berkolaborasi dengan rakan sekerja bagi mempelajari sesuatu yang baharu.

\section{Rujukan}

Bandura, A. (1986). The Explanatory and Predictive Scope of Self-Efficacy Theory, Journal of Clinical and Social Psychology, 4: 359-373.

Bandura, A. 1997. The Anatomy of stages of Change. American Journal of Health Promotion, 12: 810.

Dewi Isma Madzlan @ Madlan. (2015).Program Pembangunan Profesionalisme Guru, Faktor stress Terhadap Efikasi Guru-Guru Sekolah Menengah Di Sabah. Universiti Malaysia Sabah. (Tidak Diterbitkan). (Tesis Doktor Falsafah).

Faridah Abdullah@Muda. 2014. Pengaruh Iklim Organisasi Sekolah dan Efikasi Kolektif Terhadap Efikasi Guru-Guru Sekolah Menengah di Sabah. Universiti Malaysia Sabah. (Tidak Diterbitkan) (Tesis Doktor Falsafah)

Fuller, F.F. 1969. Concerns of teachers: a development characterization. American Education Research Journal, 6(2), 207-226.

Gay, L.R. and Diehl, P.L. (1996). Research Methods for Business and Management. In Hill, R. 1998. "What Sample Size is 'Enough' in Internet Survey Research"? Interpersonal Computing and Technology: An electronic Journal for the 21st Century.

Ghaith, G., \& Yaghi, M. (1997). Relationships Ampng Experience, Teacher Efficacy, And Attitudes Toward the Implementation Of Instructional Innovation. Teaching and Teacher Education, 13: 451-458.

Giallo, R. and Little, E. (2003). Classroom Behaviors Problems: The Relationship between Preparedness, Classroom Experiences, and Self-Efficacy in Graduate and Student Teachers. Australian Journal of Educational \& Development Psychology, 3: 21-34.

Haidi Entoh. (2019). Pengaruh Pengalaman, Kesedaran Metakognisi dan Iklim Organisasi Sekolah Terhadap Efikasi Dalam Kalangan Guru-Guru Sekolah Rendah Di Dalam Zon Banggi, Kudat. Universiti Malaysia Sabah. (Tidak Diterbitkan) (Tesis Doktor Falsafah)

Hall, G.E., dan Hord, S.M. (1987). Change in Schools: Facilitating the Process. Albany, NY: State University of New York Press. 
Hall, G.E. and Hord. S.M. (2011). Implementing change: Patterns, Principles, and Potholes (3rd ed.). Upper saddle River, NJ: Pearson.

Khalid Johari (2009). Pengaruh Pengalaman Guru Ke Atas Efikasi Guru Dan Efikasi Kolektif Di Kalangan Guru Sekolah Menengah di Sabah. Universiti Sains Malaysia. (Tidak Diterbitkan) (Tesis Doktor Falsafah).

Khalid Johari. (2016). Perkembangan Efikasi Guru Sekolah Menengah di Sabah. Jurnal Kemanusiaan, 20.

Lee Bin Saat. (2016). Pengaruh Kepimpinan Instruktional, Efikasi dan Tugas Rutin Pengetua Terhadap Pencapaian Akademik. Malaysian Journal of Social Sciences and Humanities, 1(3).

Lezah@Lejah Binti Kiamsin dan Rosy Talin. (2018). Kaedah Pengajaran Sejarah yang Diminati Pelajar dan Justifikasinya. Malaysian Journal of Social Sciences and Humanities, 3(2), 137 145.

Mohd. Mahadzir Rahimi Mohamed Nawi. (2014). Perceptions of Risky Sexual Behavior: The Role of Self-Regulation and Internet Behavior Among Students in Public University.

Muijs, D. and Reynolds, D. (2001). Being or Doing: The Role of Teacher Behaviorsand Beliefs in School and Teacher Effectiveness in Mathematics, a SEM analysis. Paper presented at the Annual Meeting of the American Educational Research Association, Seattle April 2001.

Neuman, W. L. (2006). Social Research Methods: Qualitative and Quantitative Approaches (5th ed.). Boston: Pearson Education, Inc.

Norazlin Mohd Rusdin dan Siti Rahaimah Ali. (2018). Pelaksanaan Pembelajaran Abad 21 dan Cabaran. Persidangan Penyelidikan Kualitatif (QRC) 2018 10-12 Julai 2018, Melaka, Malaysia.

Pintrich, P.R. \& Schunk, D. (2002). Motivation in Education: theory, research, and application (2nd ed.). Upper saddle, NJ: Prentice Hall, Inc.

Poulou, M. (2007). Personal Teaching Efficacy and Its Sources; Student Teachers' Perceptions. Educational Psychology, 27(2): 191-218.

Susan Senin, Nurfaradilla dan Mohamad Nasri. (2018). Keprihatinan Guru terhadap Memohon Kemahiran Pemikiran Komputasi dalam Pengajaran dan Pembelajaran. International Journal of Academic Research in Business and Social Sciences.

Tschannen-Moran, M., Hoy, A.W., and Hoy, W.K. (1998). Teacher Efficacy: Its Meaning and Measure. Review of Educational Research, 68: 202-248.

Zaidir Zainal Abidin. (2017). Tahap Pengetahun, Pemahaman, Kemahiran Dan Pelaksaanaan Guru Sains Terhadap Kemahiran Berfikir Aras Tinggi (KBAT) Journal of Advanced Research in Social and Behavioural Sciences, 8(1), 97-11397 